\title{
Occurrence of Metacaligus rufus (Wilson, 1908) (Copepoda, Caligidae) parasitizing the cownose ray Rhinoptera bonasus (Mitchill, 1815) (Elasmobranchii, Myliobatidae) in Brazil
}

\author{
R. Ducatti ${ }^{*}$, V. Takatsuka ${ }^{a}$, V. G. Azevedo ${ }^{a}$, E. G. Sanches ${ }^{a}$, F. Paschoal Pand J. L. Luque $^{c}$ \\ ${ }^{a}$ Núcleo de Pesquisa e Desenvolvimento do Litoral Norte, Instituto de Pesca, Av. Cais do Porto, 2275, CEP 11680-000, \\ Ubatuba, SP, Brazil \\ ${ }^{\text {bC } C u r s o ~ d e ~ P o ́ s-g r a d u a c ̧ a ̃ o ~ e m ~ B i o l o g i a ~ A n i m a l, ~ U n i v e r s i d a d e ~ F e d e r a l ~ R u r a l ~ d o ~ R i o ~ d e ~ J a n e i r o ~-~ U F R R J, ~ R o d o v i a ~ B R ~ 465, ~}$ \\ Km 07, s/n, Zona Rural, CEP 23890-000, Seropédica, RJ, Brazil \\ 'Departamento de Parasitologia Animal, Universidade Federal Rural do Rio de Janeiro - UFRRJ, Rodovia BR 465, Km 07, \\ s/n, Zona Rural, CEP 23890-000, Seropédica, RJ, Brazil \\ *e-mail: rhaniducatti13@hotmail.com
}

Received: February 3, 2017 - Accepted: February 24, 2017 - Distributed: October 31, 2018

(With 1 figure)

The family Caligidae are predominantly external parasites of fishes, inhabiting the outer surface, the mouth, the gills and opercular cavity of their hosts (Boxshall and Halsey, 2004). This family comprises one of the most speciose group within the Copepoda, currently encompassing 31 genera, including Metacaligus (Thomsen, 1949) which consistis of five nominal species (Walter and Boxshall, 2008). Members of Metacaligus have been associated with actinopterygian fishes or obtained from plankton, particularly from American and Asian waters (Ho and Bashirullah, 1977; Suárez-Morales et al., 2012). In the seaboard of Brazil, two species have been hitherto recorded, i.e., Metacaligus rufus (Wilson, 1908) from the gills of Merluccius sp., Oligoplites palometa (Cuvier, 1832), O. saliens (Bloch, 1793), Scomberomorus sp., Selene vomer (Linnaeus, 1758), Trichiurus lepturus (Linnaeus, 1758) and Umbrina sp.; and M. trichiuri (Krøyer, 1863) from the gills of T. lepturus (Luque and Tavares, 2007; Luque et al., 2013).

The Cownose ray Rhinoptera bonasus (Mitchill, 1815) (Myliobatidae) is an oceanic species found occasionally in sandy bottoms near the coast, feeding a variety number of bivalve mollusks and other benthic prey (Figueiredo, 1977; Froese and Pauly, 2016). This species is widely distributed in the Atlantic Ocean, found in the Western Atlantic: northern Florida (USA), throughout the Gulf of Mexico to south Brazil; and in the Eastern Atlantic: Mauritania, Senegal and Guinea (Froese and Pauly, 2016). Among the species of genus Rhinoptera, The International Union for Conservation of Nature (IUCN) listed this species as Near Threatened (NT) in relation to the state of conservation (Froese and Pauly, 2016; International Union for Conservation of Nature and Natural Resources, 2016).

One specimen of Rhinoptera bonasus (body length $46 \mathrm{~cm}$, weight $6,04 \mathrm{~kg}$ ) was caught in June 2016 in the coast of Ubatuba (2327'05.4'S, 45'02'48.4'W), State of São Paulo, southeastern Brazil. The fish was taken to the Laboratório de Piscicultura Marinha of the Instituto de Pesca de São Paulo, where it was anesthetized by immersion in eugenol K-Dent ${ }^{\circledR} 60 \mathrm{mg} / \mathrm{L}$, diluted alcohol at a ratio of 1:5 (Griffiths, 2000) for monitoring of biometrics values and ectoparasites. After monitoring, collected copepods were fixed and preserved in ethanol (70\% GL) and cleared in a drop of $85 \%$ lactic acid or lactophenol before examination using a phase-contrast microscope. Specimens were measured intact using an ocular micrometer, dissected and examined according to the wooden slide procedure of Humes and Gooding (1964). Measurements based on six females and six males are given in millimetres, unless otherwise stated, with the range followed by the mean in parentheses. Host identification was based on the key of Figueiredo (1977); the nomenclature and classification are updated according to FishBase (Froese and Pauly, 2016). Voucher specimens of M. rufus are deposited in the Crustacea Collection of the National Museum, Rio de Janeiro (MNRJ No 28601- 3q/28602 - 3§), and of the Museu de Zoologia da Universidade de São Paulo (MZUSP No 36052 - 29/36052 - 3ð̋), Brazil.

Based in the morphology of cephalothorax, genital process, abdomen, small appendages and body proportion, specimens collected in Ubatuba corresponds to the description of M. rufus given by Wilson (1908) and Suárez-Morales et al. (2012). A total of 17 specimens of M. rufus were collected, all attached the external surface of the host (Figure 1A), of these, six are mature females and eleven mature males. The following measurements were made on the specimens of $M$. rufus, collected from R. bonasus: Female (Figure 1B), Total length (excluding setae on caudal rami), 5.01-3.97 (4.33) $\mathrm{mm}$. Cephalothoracic shield oval, longer 2.71-2.59 (2.49) $\mathrm{mm}$ than wide 1.91-1.57 (1.73) mm. Genital complex roughly subrectangular (Figure 1C), longer 1.39-1.10 (1.24) mm than wide 0.81-0.72 (0.78) $\mathrm{mm}$. Abdomen widest at proximal part (Figure 1C), longer 0.73-0.44 (0.57) mm than wide 0.36-0.20(0.28) mm. Caudal 

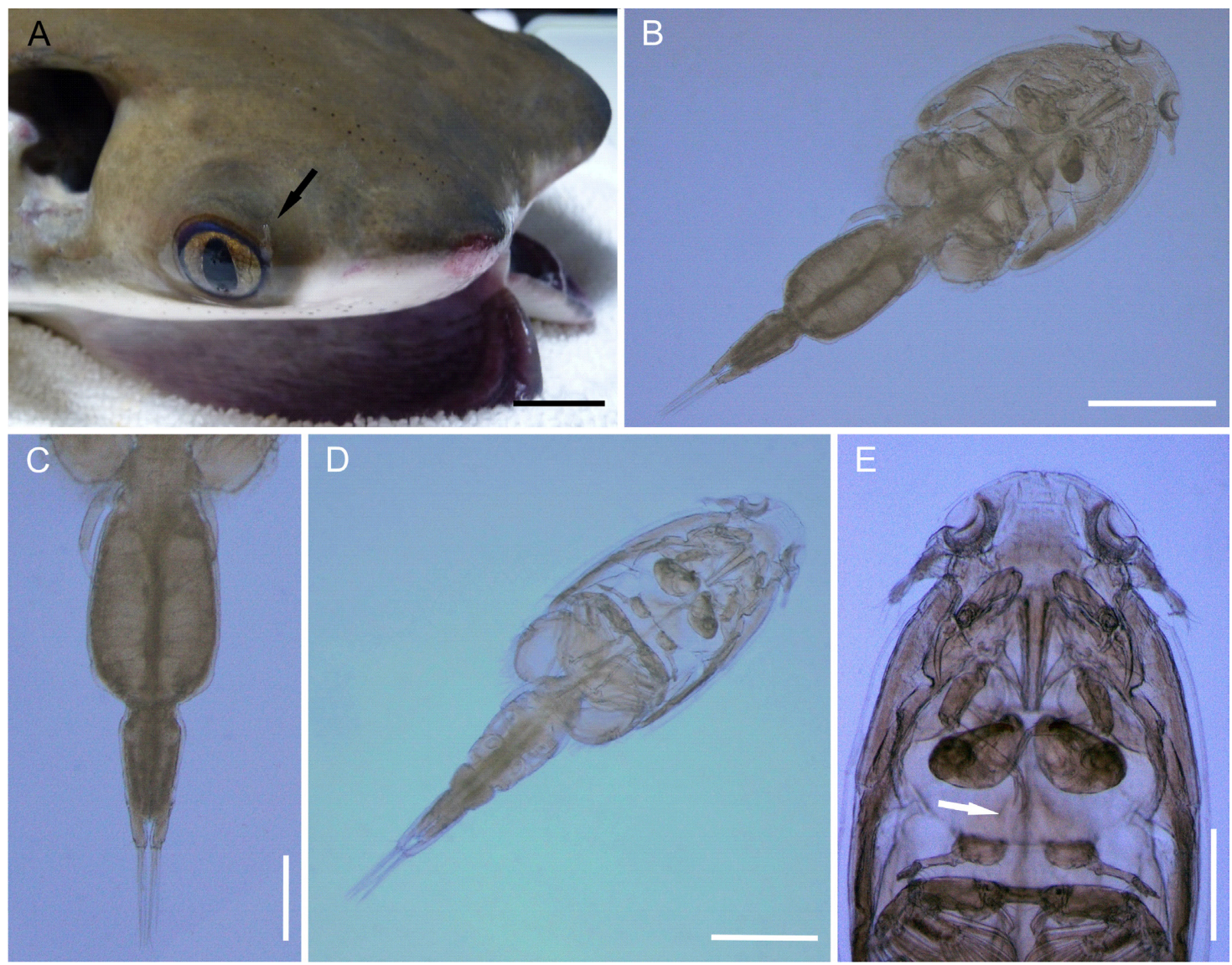

Figure 1. Metacaligus rufus (Wilson 1908). (A) Infection by female specimen on the external surface: arrow showing the specimen; (B) Female, Habitus: dorsal view; (C) Female, detail of genital complex and abdomen: ventral view; (D) Male, Habitus: dorsal view; (E) Male, anterior part of Cephalothoracic shield: arrow showing the absence of sternal furca in ventral view. Scale bars: A, 8 mm; B, D $1 \mathrm{~mm}$; C, E $500 \mu \mathrm{m}$.

rami longer 0.20-0.16(0.18) $\mathrm{mm}$ than wide $0.14-0.07(0.08) \mathrm{mm}$. Male (Figure 1D), Total length (excluding setae on caudal rami), 4.63-4.08 (4.28) $\mathrm{mm}$. Cephalothoracic shield longer 2.57-2.36 (2.44) $\mathrm{mm}$ than wide 1.75-1.57 (1.66) mm. Genital complex elongate, longer 0.93-0.88 (0.90) $\mathrm{mm}$ than wide 0.54-0.51 (0.53) mm. Abdomen 2-segmented, first segment oblong 0.29-0.26 (0.27) mm long, 0.35-0.32 (0.33) mm wide, second segment elongate longer 0.42-0.35 (0.39) $\mathrm{mm}$ than wide $0.27-0.24(0.25) \mathrm{mm}$. Caudal rami longer $0.19-0.18(0.18) \mathrm{mm}$ than wide $0.08-0.07(0.08) \mathrm{mm}$. Females specimens from Ubatuba are larger $(5.01-3.97 \mathrm{~mm})$ than the specimens collected in Chelem, Mexico (3.25-3.79 mm), and probably with similar size to the type specimens, collected in North Carolina, USA (4.4 mm) (Wilson, 1908; Suárez-Morales et al., 2012).

According to Dojiri and Ho (2013) the genus Metacaligus can be distinguished from other genera within the Caligidae by the absence of sternal furca (Figure 1E), absence of accessory process on terminal spines 2 and 3 on exopodal segment of leg 1, three short plumose setae on inner margin of second exopodal segment of leg 1 and only one outer spine on terminal exopodal segment of leg 2. Although some species of Caligus display one or two characteristics found in the genus Metacaligus, however, the presence of all features above mentioned, support Metacaligus as a validly genus (Boxshall and Halsey, 2004; Dojiri and Ho, 2013).

Metacaligus rufus was originally described by Wilson (1908) from Bagre marinus (Mitchill, 1815) in Beaufort (USA), and since its description this species has been recorded parasitizing hosts of the families Ariidae, Carangidae, Merlucciidae, Sciaenidae, Scombridae and Trichiuridae (Luque and Tavares, 2007; Suárez-Morales et al., 2012; Luque et al., 2013). The probable dissemination of this caligid copepod on the elasmobranch host occurred through the B. marinus that occurs in some regions with $R$. bonasus, inhabiting over mud and sandy bottoms of the coast of Gulf of Mexico, Cuba, western margin of the Caribbean, and the northern margin of South America (Robins and Ray, 1986; Froese and Pauly, 2016).

Records of parasitic copepods on elasmobranch fishes in Brazil are scarce, and today of the 211 known species copepods found to parasite fishes in the Brazilian coast, only 16 have been reported from cartilaginous fishes, 
accounting for $10 \%$ of the total (Luque et al., 2013; Paschoal et al., 2016; Taborda et al., 2016). To date, there are no previous records of parasitic copepods on the cownose ray, for this in the present paper we documented the first record of a caligid copepod on $R$. bonasus, and the first occurrence of $M$. rufus parasitizing an elasmobranch host into world's oceans.

\section{References}

BOXSHALL, G.A. and HALSEY, S.H., 2004. An introduction to copepod diversity. London: The Ray Society. $940 \mathrm{p}$.

DOJIRI, M. and HO, J.S., 2013. Systematics of the Caligidae, copepods parasitic on marine fishes. Crustaceana Monograph Series, vol. 18, pp. 448.

FIGUEIREDO, J.L., 1977. Manual de peixes marinhos do Sudeste do Brasil. I. Introdução: cações, raias e quimeras. São Paulo: Museu de Zoologia, Universidade de São Paulo. 104 p.

FROESE, R. and PAULY, D., eds., 2016 [viewed 6 November 2016]. FishBase [online]. Available from: www.fishbase.org

GRIFFITHS, S.P., 2000. The use of clove oil as an anaesthetic and method for sampling intertidal rockpool fishes. Journal of Fish Biology, vol. 57, no. 6, pp. 1453-1464. http://dx.doi. org/10.1111/j.1095-8649.2000.tb02224.x.

HO, J.S. and BASHIRULLAH, A.K.M., 1977. Two species of caligid copepods (Crustacea) parasitic on marine fishes of Venezuela, with discussion of Metacaligus Thomsen, 1949. Journal of Natural History, vol. 11, no. 6, pp. 703-714. http:// dx.doi.org/10.1080/00222937700770601.

HUMES, A.G. and GOODING, R.U., 1964. A method for studying the external anatomy of Copepods. Crustaceana, vol. 6, no. 3, pp. 238-240. http://dx.doi.org/10.1163/156854064X00650.

INTERNATIONAL UNION FOR CONSERVATION OF NATURE AND NATURAL RESOURCES - IUCN, 2016 [viewed 20 October
2016]. Red List of Threatened Species [online]. Cambridge. Available from: http//:www.iucnredlist.org

LUQUE, J.L. and TAVARES, L.E.R., 2007. Checklist of Copepoda associated with fishes from Brazil. Zootaxa, vol. 1579, pp. 1-39.

LUQUE, J.L.; VIEIRA, F.M.; TAKEMOTO, R.M.; PAVANELLI, G.C. and EIRAS, J.C., 2013. Checklist of Crustacea parasitizing fishes from Brazil. Journal of Species List and Distribution, vol. 9, no. 6, pp. 1449-1470.

PASCHOAL, F., NAGASAWA, K. and LUQUE, J.L., 2016. A new species of Leposphilus Hesse, 1866 (Copepoda: Philichthyidae) parasitic in the interorbital canals of the whitemouth croaker Micropogonias furnieri (Desmarest) (Sciaenidae) off Brazil with an amended diagnosis of the genus. Systematic Parasitology, vol. 93, no. 5, pp. 501-515. PMid:27221003.http://dx.doi.org/10.1007/ s11230-016-9637-9.

ROBINS, C.R. and RAY, G.C., 1986. A field guide to Atlantic coast fishes of North America. Boston: Houghton Mifflin Company. $354 \mathrm{p}$

SUÁREZ-MORALES, E.; KIM, I.H. and ESCAMILLA, B.J., 2012. On some caligids (Copepoda: Caligidae) from plankton of a Coastal Lagoon in the Gulf of Mexico with a description of a new species of Metacaligus. Zoological Studies, vol. 51, no. 6, pp. 804-818.

TABORDA, N.L., PASCHOAL, F. and LUQUE, J.L., 2016. A new species of Ergasilus (Copepoda: Ergasilidae) from Geophagus altifrons and G. argyrostictus (Perciformes: Cichlidae) in the Brazilian Amazon. Acta Parasitologica, vol. 61, no. 3, pp. 549555. PMid:27447219. http://dx.doi.org/10.1515/ap-2016-0073.

WALTER, T.C. and BOXSHALL, G.A., 2008 [viewed 5 November 2016]. World of Copepods database [online]. Available from: www.marinespecies.org/copepoda

WILSON, C.B., 1908. North American parasitic copepods: new genera and species of Caliginae. Proceedings of the United States National Museum, vol. 33, pp. 593-643. 